\title{
Effect of progesterone on Candida albicans vaginal pathogenicity
}

\author{
Carlos Tiago Alves ${ }^{\mathrm{a}}$, Sónia Silva ${ }^{\mathrm{a}}$, Leonel Pereira ${ }^{\mathrm{a}}$, David W. Williams ${ }^{\mathrm{b}, * *}$, \\ Joana Azeredo ${ }^{a}$, Mariana Henriques ${ }^{\mathrm{a}, *}$ \\ a IBB-Institute for Biotechnology and Bioengineering, Centre of Biological Engineering, University of Minho, 4710-057 Braga, Portugal \\ b Tissue Engineering \& Reparative Dentistry, School of Dentistry, Cardiff University, Cardiff CF4 4XY, United Kingdom
}

\section{A R T I C L E I N F O}

\section{Article history:}

Received 3 May 2014

Received in revised form 16 July 2014

Accepted 20 July 2014

\section{Keywords:}

Progesterone

Biofilm

RHVE

Vulvovaginal candidiasis

Candida albicans

\begin{abstract}
A B S T R A C T
Candida albicans is responsible for the majority of cases of vulvovaginal candidiasis (VVC), an infection which occurs mainly during the luteal phase of the menstrual cycle or during the pregnancy, when levels of progesterone are elevated. One of the most important candidal virulence factors is the ability to adhere to host surfaces and form biofilms.

The aim of this study was to determine the influence of progesterone on C. albicans virulence, namely biofilm formation and colonisation/invasion of a reconstituted human vaginal epithelium (RHVE). Biofilm formation on the RHVE was evaluated by enumeration of culturable cells, total mass quantification and scanning electron microscopy. The capacity of $C$. albicans strains to invade and colonise the tissue was examined by fluorescence microscopy using species-specific peptide nucleic acid (PNA) probe hybridisation, and quantitatively evaluated by RT-PCR Candida quantification methodology. Furthermore, gene (BCR1 and HWP1) expression of biofilm and RHVE-colonising cells was evaluated by quantitative RT-PCR. Results confirmed that progesterone reduced the capacity of $C$. albicans strains to form biofilms and to colonise and invade RHVE. Additionally, it was demonstrated that progesterone decreased expression of $B C R 1$ and HWP1, which are important virulence determinants of $C$. albicans. In conclusion, it was evident that progesterone can have a major influence on C. albicans pathogenicity on vaginal epithelial cells and may partly explain susceptibility of women to VVC at different stages of the menstrual cycle.
\end{abstract}

(c) 2014 Elsevier GmbH. All rights reserved.

\section{Introduction}

Yeast species of the genus Candida are responsible for 70-90\% of human fungal infections, with Candida albicans accounting for approximately $50 \%$ of all yeasts isolated from clinical samples (Eggimann et al., 2003). Interestingly, there has been a notable increase in the relative proportion of infections caused by nonCandida albicans Candida (NCAC) species (Trick et al., 2002). However, C. albicans is still regarded to be the most virulent Candida species. Infection with $C$. albicans represents an important public health challenge with high economic and medical relevance due to the increased costs of care, time of hospitalisation and high levels of morbidity and mortality rates, especially in immunocompromised patients (Sardi et al., 2013).

Vulvovaginal candidiasis (VVC) is an opportunistic fungal infection, caused by Candida species, that affects between 29 and $45 \%$

\footnotetext{
* Corresponding author. Tel.: +351 253604408; fax: +351253604429.

** Corresponding author. Tel.: +4402920742548.

E-mail addresses: williamsdd@cf.ac.uk (D.W. Williams), mcrh@deb.uminho.pt (M. Henriques).
}

of healthy women during their lifetime in European countries (Foxman et al., 2013) and approximately 75\% of women of gestation age in the United States (Sobel, 1992; Sobel et al., 1998).

The pathogenesis of VVC involves the initial adherence of the yeast to the vaginal mucosa, followed by asymptomatic colonisation, ultimately leading to infection (symptomatic vaginitis) (Taguti Irie et al., 2006). This occurs when the colonisation site of the host becomes favourable to the growth of yeast, which is normally restricted to asymptomatic colonisation and limited by immunological host responses. Conditions associated with enhanced colonisation include host immunosuppression, diabetes mellitus and pregnancy. The use of antibiotics and oral contraceptives that contain high levels of oestrogen also seem to be contributory predisposing factors (Sobel, 1992; Spinillo et al., 1999). In the absence of these factors, clinical observations show that VVC occurs predominantly during the luteal phase of the menstrual cycle, when levels of progesterone and oestrogen are elevated. In contrast, pre-menstrual girls and post-menopausal women who are not receiving hormone replacement therapy, rarely exhibit VVC (Kalo and Segal, 1988). However, the mechanisms by which these hormones act in VVC are not fully known (Fidel et al., 2000; Miller et al., 2000). 
Amongst the putative virulence factors of Candida are the ability to express adhesins to adhere to host tissues and also produce biofilms (Ramage et al., 2005). Biofilms are microbial communities associated with biotic or abiotic solid surfaces. Cells in a biofilm display phenotypes that are distinct from their free-living counterparts, including increased resistance to typical antifungal drugs (Douglas, 2003; Ramage et al., 2012). Biofilm formation is, in part, dependent upon expression of the $C$. albicans transcription factor biofilm cell wall regulator (BCR1) (Fanning et al., 2012). Host cell recognition and colonisation by Candida is also facilitated by adhesins, such as hyphal wall protein (HWP) (Calderone and Gow, 2002), which is expressed by the hyphal form of $C$. albicans. Importantly, the effect of progesterone on expression of these virulence factors is not known and could be a contributory influence on Candida biofilm formation and vaginal human epithelial colonisation and invasion.

This current work aimed to investigate the influence of progesterone on $C$. albicans biofilm formation on a reconstituted human vaginal epithelium (RHVE). The colonisation/invasion of this tissue by $C$. albicans was assessed together with the expression of $B C R 1$ and HWP1 during C. albicans biofilm development.

\section{Material and methods}

\section{Organisms and growth conditions}

Two Candida albicans strains were used in this work, which were a reference strain C. albicans ATCC 90028 from the American Type Culture Collection (ATCC) and a vaginal isolate, namely C. albicans 558234 , acquired from the biofilm group of the Centre of Biological Engineering, Minho University (Braga, Portugal) and previously isolated from a patient of the Hospital of S. Marcos, Braga, Portugal. The identity of the isolate was confirmed using CHROMagar®Candida (CHROMagar, France) and by PCR-based sequencing using specific primers ITS1 (5'-TCCGTAGGTGAACCTGCGG-3') and ITS4 (5'-TCCTCCGCTTATTGATATGC-3') (Williams et al., 1995).

All Candida strains were subcultured on Sabouraud dextrose agar (SDA; Merck, Germany) at $37^{\circ} \mathrm{C}$ for $48 \mathrm{~h}$. An inoculum of each strain, obtained from SDA plates, was suspended in $20 \mathrm{~mL}$ of Sabouraud dextrose broth (SDB; Merck, Germany) and incubated at $37^{\circ} \mathrm{C}$ for $18 \mathrm{~h}$ under agitation ( $\left.120 \mathrm{rev} / \mathrm{min}\right)$. Then, the cells were harvested by centrifugation at $3000 \times \mathrm{g}$ for $10 \mathrm{~min}$ at $4{ }^{\circ} \mathrm{C}$ and washed twice with $15 \mathrm{~mL}$ of phosphate buffered saline (PBS; pH 7). Pellets were suspended in RPMI (Sigma, St Louis, $\mathrm{MO}$ ), buffered to $\mathrm{pH} 4.0$ and the cellular density adjusted for each experiment, using a Neubauer haemocytometer (Marienfeld, LandKönigshofen, Germany).

\section{Effect of progesterone on Candida albicans biofilm formation}

In order to study the effect of progesterone on $C$. albicans biofilm formation, progesterone (Sigma Saint Louis, Missouri, USA) was added at the beginning of the biofilm-formation process. To the wells of 96-well microtiter plates (Orange Scientific, Brainel'Alleud, Belgium), $200 \mu$ L of Candida suspension containing $1 \times 10^{7}$ cells $\mathrm{mL}^{-1}$ with $2 \mu \mathrm{M}$ of progesterone in RPMI ( $\mathrm{pH} 4$ ) was added. The progesterone concentration was selected according to the levels present in the plasma of pregnant women in the third trimester (Nohmi et al., 1995). The microtiter plates were incubated at $37^{\circ} \mathrm{C}$ under agitation ( $120 \mathrm{rev} / \mathrm{min}$ ) for $24 \mathrm{~h}$. Yeast cultures without progesterone and controls without Candida were also included, all at $\mathrm{pH}$ 4. After incubation, the medium was aspirated and the biofilms washed once with $200 \mu \mathrm{L}$ of PBS to remove non-adherent cells. All experiments were performed in triplicate and in a minimum of three independent assays.

\section{Quantification of cultivable cells from biofilms}

Biofilms were physically removed from the wells using a pipette tip and the suspensions were vigorously vortex mixed for 2 min to disaggregate cells. Serial decimal dilutions of recovered cells in PBS were plated on SDA and incubated for $24 \mathrm{~h}$ at $37^{\circ} \mathrm{C}$. The results were presented as total colony forming units (CFUs) per unit area $\left(\log _{10}\right.$ CFUs $\mathrm{cm}^{-2}$ ) (Silva et al., 2009).

\section{Quantification of biofilm biomass}

Total biofilm biomass was quantified using a crystal violet (CV) staining methodology (Silva et al., 2009). Biofilms in the microtiter plate wells were fixed with $200 \mu \mathrm{L}$ of methanol for $15 \mathrm{~min}$. The methanol was removed and the microtiter plates were allowed to dry at room temperature. A $200-\mu \mathrm{L}$ volume of crystal violet (CV; $1 \%, v / v$ ) was then added to each well. After $5 \mathrm{~min}$, the excess of $\mathrm{CV}$ was removed and the biofilms were gently washed $(\times 2)$ with water. Finally $200 \mu \mathrm{L}$ of acetic acid (33\%, v/v) was added to each well to release and dissolve the CV stain. The absorbance of the CV solutions was then measured at $570 \mathrm{~nm}$ and results presented as absorbance per unit area $\left(\mathrm{Abs} \mathrm{cm}^{-2}\right)$.

\section{Characterisation of biofilm structure}

The structure of biofilms and morphology of Candida in the presence and absence of progesterone was also characterised by scanning electron microscopy (SEM). Preparation of biofilms was as described above, but 24-well microtiter plates (orange Scientific, Braine-l'Alleud, Belgium) were used. Developed biofilms were dehydrated with increasing concentrations of ethanol (using 70\% ethanol for $10 \mathrm{~min}, 95 \%$ ethanol for $10 \mathrm{~min}$ and $100 \%$ ethanol for $20 \mathrm{~min}$ ) and then air dried for $20 \mathrm{~min}$. Samples were kept in a desiccator until analysis. Prior to observation, the base of the wells were removed and mounted on aluminium stubs, sputter coated with gold and imaged using an S-360 scanning electron microscope (Leo, Cambridge, USA).

\section{Effect of progesterone on Candida albicans colonisation and invasion of RHVE}

RHVE tissues (SkinEthic Laboratories, Lyon, France) were inoculated for $24 \mathrm{~h}$ with $1 \mathrm{~mL}$ of standardised $C$. albicans suspension $\left(2 \times 10^{6}\right.$ cells $\left.\mathrm{ml}^{-1}\right)$ prepared in maintenance medium (SkinEthic Laboratories, Lyon, France) and adjusted to $\mathrm{pH} 4$ in the presence and absence of $2 \mu \mathrm{M}$ of progesterone. Tissues devoid of progesterone or C. albicans were also included. All controls were performed at $\mathrm{pH} 4$. To determine the effects of progesterone on the measured parameters, the RHVE was also firstly incubated for $12 \mathrm{~h}$ with $1 \mathrm{~mL}\left(2 \times 10^{6}\right.$ cells $\mathrm{ml}^{-1}$ ) of each $C$. albicans strain in the absence of progesterone. The tissue was then washed $(\times 1)$ with $1 \mathrm{~mL}$ of PBS to remove nonadherent cells and $1 \mathrm{~mL}$ of maintenance medium with $2 \mu \mathrm{M}$ of progesterone was added to each tissue. All infected tissues were incubated at $37^{\circ} \mathrm{C}$ in a $5 \% \mathrm{CO}_{2}$ environment in a saturated humidity for the required time period. After incubation, tissues were washed $(\times 2)$ with $1 \mathrm{~mL}$ of PBS to remove non-adherent Candida. Tissues were then bisected, with one-half being used for fluorescence microscopy and the other for molecular studies.

\section{Microscopic observation}

The RHVE half of the tissue for microscopic analysis was fixed in $2 \%(\mathrm{v} / \mathrm{v})$ formalin and stored at $4{ }^{\circ} \mathrm{C}$ until histological processing. Tissues were then dehydrated, cleared and infiltrated with paraffin wax-embedding material. The formalin-fixed paraffin-embedded (FFPE) tissues were stored at room temperature. The tissues were 
cut (5 $\mu \mathrm{m}$ sections) and placed on Histobond + coated microscope slides (Raymond A Lamb, East Sussex, UK), de-waxed and processed through xylene, ethanol and water before peptide nucleic acid probe hybridization (PNA FISH).

PNA FISH was employed on tissue sections using the Light PNA FISH $^{\mathrm{TM}}$ kit (AdvanDx Inc., Woburn MA, USA). The species-specific PNA probes were used to ascertain the extent of invasion and colonisation of the RHVE by C. albicans. The assay was performed in accordance with the guidelines of the manufacturer. Tissue sections on microscope slides were overlaid with one drop of PNA probe. After 90 min of incubation in the dark and in a humidified chamber at $55^{\circ} \mathrm{C}$, unbound probe was removed by washing the slides using a previously warmed wash solution at $55^{\circ} \mathrm{C}$ for $30 \mathrm{~min}$. The preparation was then mounted with a medium (Vectashield, Vector laboratories, California, USA) suitable for fluorescence microscopy, which also contained 4',6-diamidino-2-phenylindole (DAPI) for detection of epithelial cell nuclei.

Tissue sections $(5 \mu \mathrm{m})$ hybridised with PNA probes were observed by fluorescence microscopy, using a BX51 Olympus fluorescence microscope coupled with a DP71 digital camera (Olympus Portugal SA, Porto, Portugal). A specific classification scale was used to express the level of $C$. albicans RHVE colonisation. Colonisation categories were as follows: extensive (fungal elements totally covered the surface); moderate (fungal elements covered a large proportion of surface) and sparse (fungal elements covered only limited areas of surface). Similarly, the following categories defined the level of Candida RHVE invasion: high (fungal elements totally invaded all RHVE keratinocytes layers); moderate (fungal elements moderately invaded the first RHVE top keratinocytes layers) and low (fungal elements only formed isolated clusters in the first RHVE keratinocyte layer).

\section{Quantification of Candida cells in RHVE tissue sections}

\section{DNA extraction}

From the remaining FFPE tissue, four tissue sections of $5 \mu \mathrm{m}$ were cut and placed in sterile $1.5-\mathrm{mL}$ microcentrifuge tubes (Eppendorf AG, Hamburg, Germany). Paraffin was removed using $1 \mathrm{~mL}$ of xylene and the tubes vigorously vortexed for $10 \mathrm{~s}$. After centrifugation $(13,000 \times g$ for $2 \mathrm{~min})$, the supernatant was discarded and the residual xylene removed from the tissue pellet by adding $1 \mathrm{~mL}$ of absolute ethanol. After repeated centrifugation, the supernatant was carefully removed. The tubes were left open for $10 \mathrm{~min}$ at room temperature and DNA for PCR analysis was extracted from the tissue pellet using a commercial DNA extraction kit (QIAamp®) DNA FFPE Tissue, Qiagen).

\section{Quantification of Candida by real-time PCR}

Candida albicans were quantified using real-time PCR employing a CF X96 Real-Time PCR System (Bio-Rad, Berkeley, USA). Each reaction mixture consisted of $10 \mu \mathrm{L}$ of working concentration of SsoFast EvaGreen Supermix (Bio-Rad, Berkeley, USA), $0.2 \mu \mathrm{L}$ of each primer $(50 \mu \mathrm{M})$ designed previously (Table 1$))$ and $4 \mu \mathrm{L}$ of DNA, in a final reaction volume of $20 \mu \mathrm{L}$. Negative controls were performed using a reaction mixture with nuclease free $\mathrm{H}_{2} \mathrm{O}$ (Cleaver Scientific Ltd, UK) substituting for the template DNA. Template DNA for each positive control was obtained from FFPE tissues after the step of DNA extraction described above. PCR cycling conditions consisted of an initial denaturation step at $98^{\circ} \mathrm{C}$ for $2 \mathrm{~min}$, followed by 40 cycles of denaturation at $98^{\circ} \mathrm{C}$ for $5 \mathrm{~s}$ and primer annealing at $60^{\circ} \mathrm{C}$ for $5 \mathrm{~s}$. In each cycle, a dissociation stage of $60^{\circ} \mathrm{C}$ was run to generate a melting curve for confirmation of the specificity of the amplification product. Calibration curves $\left(C_{t}\right.$ vs. $\log$ cells) for each $C$. albicans strain were constructed using the same PCR protocol as described above. For these, serial dilutions of Candida were prepared using an improved Neubauer haemocytometer (Marienfeld, Land-Königshofen, Germany) and the DNA for PCR analysis extracted from the cell pellet using the DNA extraction kit (QIAamp ${ }^{\circledR}$ DNA FFPE Tissue, Qiagen, Crawley, UK) with some modifications.

\section{Analysis of HWP1 and BCR1 gene expression in C. albicans biofilms}

\section{Candida RNA extraction}

For gene expression analysis, biofilms were prepared in the presence ( $2 \mu \mathrm{M}$ progesterone) and absence of progesterone as described above, in both microtiter plates and RHVE. In the case of microtiter plate biofilms, the culture medium was removed and the wells washed with $1 \mathrm{~mL}$ of $\mathrm{PBS}$ ( $\mathrm{pH} 7$ ) to remove non-adherent cells. The biofilms were then physically removed from wells by scraping with a pipette tip, and resuspended in $1 \mathrm{~mL}$ of PBS and sonicated (Ultrasonic Processor, Cole-Parmer, Illinois, USA) for $30 \mathrm{~s}$ at $30 \mathrm{~W}$ to separate the cells from the biofilm matrix. Cells were harvested by centrifugation at $8000 \times \mathrm{g}$ for $5 \mathrm{~min}$ at $4{ }^{\circ} \mathrm{C}$ and collected in a $1.5-\mathrm{mL}$ microcentrifuge tube (QIAshredder ${ }^{\circledR}$, Qiagen, Crawley, UK).

For RNA extraction from Candida adhered to tissues, fresh RHVE tissue was removed with a scalpel directly from the plastic scaffold and placed in a $1.5-\mathrm{mL}$ microcentrifuge tube (QIAshredder ${ }^{\circledR}$, Qiagen, Crawley, UK). To each microcentrifuge tube (QIAshredder®, Qiagen, Crawley, UK) $600 \mu$ L of RLT buffer containing $500 \mu$ L of glass beads $(0.5 \mathrm{~mm}$ diameter) and $1 / 100(\mathrm{v} / \mathrm{v})$ of $\beta$-mercaptoethanol was added. These mixes were homogenised twice for $30 \mathrm{~s}$ using a Mini-Bead-Beater-8 (Stratech Scientific, Soham, UK). After cell disruption, the PureLink ${ }^{\circledR}$ RNA Mini Kit (Invitrogen, Carlsbad, USA) was used for total RNA extraction according to the manufacturer's recommended protocol. To remove any DNA contamination, samples were treated with RNase-Free DNase I (Invitrogen, Carlsbad, USA). The RNA extraction was performed on three different independents assays.

\section{Synthesis of $c D N A$}

To synthesise complementary DNA (cDNA), the iScript cDNA Synthesis Kit (Bio-Rad) was used according to the manufacturer's instructions. For each sample, $0.5 \mu \mathrm{g}$ of the extracted RNA was used for cDNA synthesis. cDNA synthesis was performed firstly at $70^{\circ} \mathrm{C}$ for $5 \mathrm{~min}$ and then at $42^{\circ} \mathrm{C}$ for $1 \mathrm{~h}$. The reaction was stopped by heating for $5 \mathrm{~min}$ at $95^{\circ} \mathrm{C}$.

\section{Gene selection and primer design for quantitative real-time PCR}

Primers for the 'housekeeping' genes (ACT1_alb), and putative virulence genes (HWP1, BCR1) were designed using Primer3 web software (http://fokker.wi.mit.edu). Full-length gene sequences were obtained from the $C$. albicans database http://www.candidagenome.org (Skrzypek et al., 2010). The specificity of each primer was confirmed by comparing its respective sequences to the $C$. albicans database using BLAST (Altschul et al., 1997). To verify the specificity of each primer pair for its corresponding target gene, PCR, using the various primer pairs, was applied to genomic DNA extracted from each of the $C$. albicans strains. The sequences of the primers developed in the present study are provided in Table 1. 
Table 1

Forward (FW) and reverse (RV) primers used for real-time PCR.

\begin{tabular}{|c|c|c|c|}
\hline & Sequence $\left(5^{\prime} \rightarrow 3^{\prime}\right)$ & Orientation & Target \\
\hline \multirow[t]{2}{*}{ C. albicans identification } & GAGCGTCGTTTCTCCСTCAAACCGCTGG & FW & \multirow[t]{2}{*}{ C. albicans } \\
\hline & GGTGGACGTTACCGCCGCAAGCAATGTT & RW & \\
\hline \multirow[t]{2}{*}{ ACT1 gene } & TGCTGAACGTATGCAAAAGG & FW & \multirow[t]{2}{*}{ ACT1 } \\
\hline & TGAACAATGGATGGACCAGA & RV & \\
\hline \multirow[t]{2}{*}{ HWP1 gene } & TCTACTGCTCCAGCCACTGA & FW & \multirow[t]{2}{*}{ HWP1 } \\
\hline & CCAGCAGGAATTGTTTCCAT & RV & \\
\hline \multirow[t]{2}{*}{ BCR1 gene } & GGCTGTCCATGTTGTTGTTG & FW & \multirow[t]{2}{*}{ BCR1 } \\
\hline & GAGCACGCATCTATGGCTTA & RV & \\
\hline
\end{tabular}

Quantitative real-time PCR ( $q R T$-PCR)

qRT-PCR (CF X96 Real-Time PCR System; Bio-Rad, Berkeley, USA) was used to determine the relative levels of HWP1 and BCR1 mRNA transcripts in the biofilm samples, with ACT1 used as a reference housekeeping gene. Each reaction mixture consisted of $10 \mu \mathrm{L}$ (working concentration) of SsoFast EvaGreen Supermix (Bio-Rad, Berkeley, USA), $0.2 \mu \mathrm{L}$ of forward and reverse primers $(50 \mu \mathrm{M})$ (Table 1), $5.6 \mu \mathrm{L}$ of $\mathrm{dH}_{2} \mathrm{O}$ (Cleaver Scientific Ltd, UK), $4 \mu \mathrm{L}$ of twofold diluted cDNA samples together with the respective target gene primers. Negative controls $\left(\mathrm{dH}_{2} \mathrm{O}\right)$, as well as, non- reverse transcriptase controls (NRT) were included in each run. Real-time PCR was performed with an initial denaturation step at $98^{\circ} \mathrm{C}$ for $2 \mathrm{~min}$, followed by 40 cycles of denaturation at $98^{\circ} \mathrm{C}$ for $5 \mathrm{~s}$, and primer annealing at $58^{\circ} \mathrm{C}$ for $5 \mathrm{~s}$. In each cycle, a dissociation stage at $60^{\circ} \mathrm{C}$ was run to generate a melting curve for verification of amplification product specificity. Control samples were included on each plate to ensure that multiple plates could be compared. The $C_{t}$ value of each sample was determined, and the relative gene expression levels calculated using the $\Delta C_{t}$ method (Livak and Schmittgen, $2001)$, which was normalised to the housekeeping gene $\left(C_{t}\right.$ average $=25.3 \pm 0.36$ ). Each reaction was performed in triplicate and mean values of relative expression were determined for each gene.

\section{Statistical analysis}

Results were compared using a two-way ANOVA with the Bonferroni test, using GraphPad Prism 6 software. All tests were performed with a confidence level of $95 \%$.

\section{Results}

Influence of progesterone on biofilm formation by Candida albicans

Initially, Candida growth curves were determined in RPMI (buffered to $\mathrm{pH} 4$ ) with and without progesterone and no effect was observed in the normal yeast growth (data not shown). Then, biofilm formation of two different $C$. albicans strains, in the presence $(2 \mu \mathrm{M})$ or absence of progesterone, was evaluated using CFU enumeration (Fig. $1 \mathrm{~A}$ ) and CV staining (Fig. 1B).

It was evident that the presence of progesterone significantly reduced the biofilm formation of both strains (Fig. 1). The number of viable cells [ $\left.\log \left(\mathrm{CFUs} / \mathrm{cm}^{2}\right)\right]$ (Fig. 1A) decreased by approximately $3 \log _{10}$ in case of $C$. albicans ATCC $90028(p<0.001)$ and $2 \log _{10}$ in the case of $C$. albicans $558234(p<0.001)$. Similarly, a significant decrease in total biomass values $(p<0.001)$ occurred in the presence of progesterone in RPMI medium for both Candida strains (Fig. 1B).

SEM analysis was used to examine biofilm structure and to determine possible differences concerning Candida morphological characteristics (Fig. 2).

Biofilms of $C$. albicans exhibited different structures and cell morphologies depending on culture environment conditions (Fig. 2). Biofilms formed by both C. albicans strains in the absence of progesterone exhibited both yeast and hyphal morphology. However, biofilms of $C$. albicans ATCC 90028 formed a multilayered and compact biofilm that covered the entire surface. Biofilms of $C$. albicans 558234 consisted of non-contiguous cell aggregates with less hyphal forms. However, in the presence of $2 \mu \mathrm{M}$ of progesterone, biofilms were greatly reduced in cell number and presence of hyphal forms.

Expression of the biofilm cell wall regulator 1 (BCR1) and hyphal wall protein (HWP1) genes were determined in an effort to understand the basis behind the observed biofilm changes following SEM. Results of these studies are presented in Fig. 3 and expressed as the mean percentage expression, relative to the expression of $A C T 1$ during biofilm formation. ACT1 gene expression levels were constant in all assays.

The results (Fig. 3) showed that both BCR1 and HWP1 expression varied in a strain-dependent manner and with the presence of progesterone. It is important to highlight that in the presence of progesterone there was a statistically significant $(p<0.001)$ down regulation of gene expression for both strains.
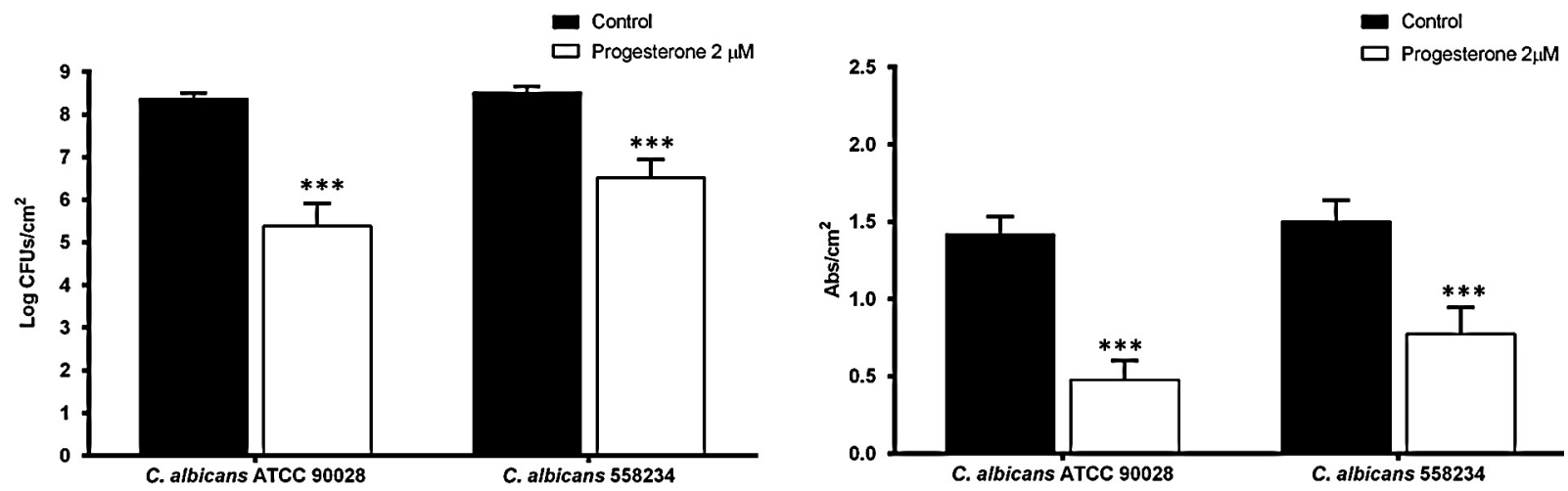

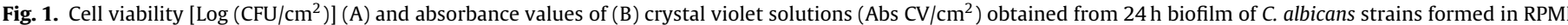

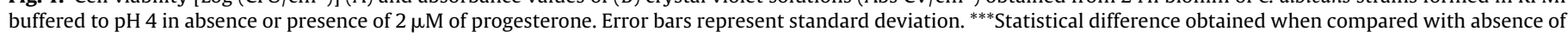
$2 \mu \mathrm{M}$ of progesterone (control) $(p<0.001)$. 




Fig. 2. Scanning electron microscopy of $C$. albicans 24 -h biofilms formed in RPMI in the absence or presence of $2 \mu M$ of progesterone. Original magnification was $\times 1000$.

BCR1

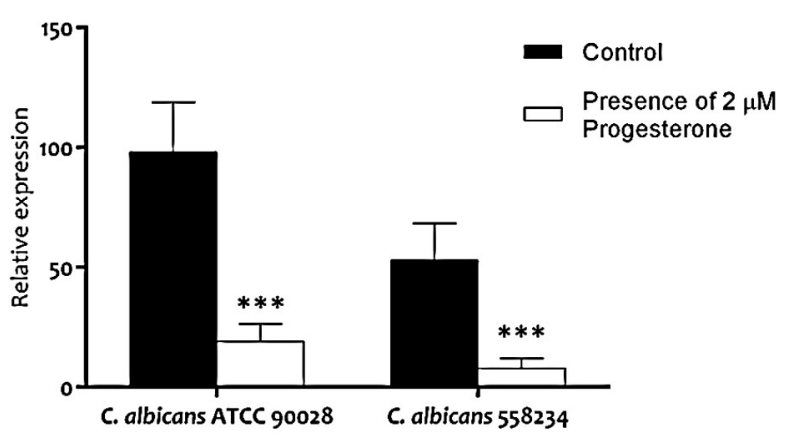

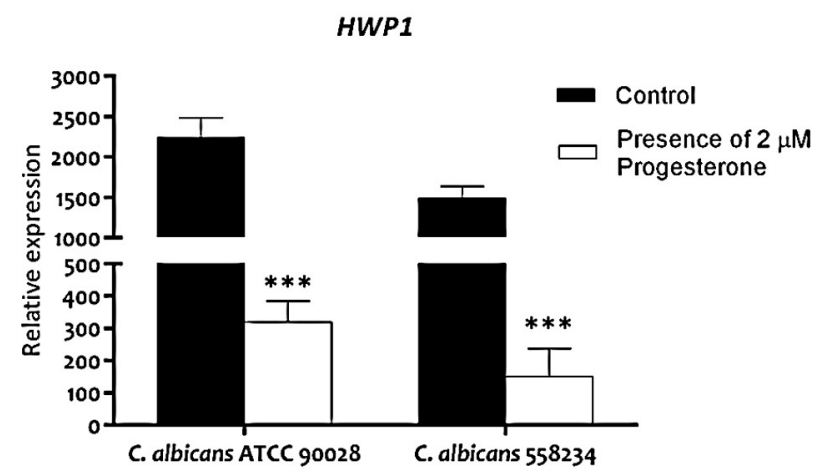


Error bars represent standard deviation. ${ }^{* * *}$ Statistical difference obtained when compared with absence of progesterone $(p<0.001)$.

Influence of progesterone on RHVE colonisation and invasion by $C$. albicans

Candida albicans colonisation and invasion of RHVE was examined after $24 \mathrm{~h}$ of infection. Progesterone $(2 \mu \mathrm{M})$ was added at two different time points at the beginning and after $12 \mathrm{~h}$ of colonisation (Fig. 4 and Table 2). The addition of progesterone, at $12 \mathrm{~h}$ was performed to compare its influence in the development of RHVE infection by C. albicans.

The results showed that for both strains and in all conditions tested, colonisation of the RHVE occurred. However, the degree of colonisation varied with strain and the presence of progesterone. Candida albicans 558234 (vaginal isolate) exhibited the highest level of colonisation (moderate) in the absence of progesterone (Fig. 4D). Under the same environmental conditions, C. albicans ATCC 90028 exhibited sparse colonisation (Fig. 4A). Additionally, both $C$. albicans strains demonstrated sparse colonisation in the presence of progesterone (Fig. 4B and E). In general, after 24- and 12-h exposure to progesterone, only a few clusters of $C$. albicans were detected on the surface of the RHVE layers (Fig. 4C and F). Furthermore, only C. albicans 558234 appeared to be able to invade the epithelium (Fig. $4 \mathrm{D}$ and F).

Real-time PCR was used to quantify the number of infecting C. albicans under the different conditions tested (Table 2). qRTPCR showed that both $C$. albicans strains were present at higher numbers in the RHVE sections infected without progesterone $(p<0.001)$, thereby supporting the findings of the fluorescence microscopy. There were no discernible differences in terms of Candida quantification when progesterone was added at time point 0 or at $12 \mathrm{~h}$. It was noted that C. albicans 558234 (vaginal strain) was always present in a higher number than C. albicans ATCC 90028.

HWP1 expression was measured to better understand the effect of progesterone on RHVE colonisation and invasion. Fig. 5 presents the mean $n$-fold expression levels of HWP1 by $C$. albicans ATCC 90028 and C. albicans 558234 infecting the RHVE. The controls represent gene expression in absence of progesterone.

The results presented in Fig. 5, indicate that HWP1 expression was strain dependent and was significantly reduced by the presence of progesterone $(p<0.001)$. HWP1 expression was dependent on time of contact with progesterone, since after a pre-period of infection $(12 \mathrm{~h})$ without progesterone had higher expression of HWP1 gene compared to addition at $0 \mathrm{~h}$.

\section{Discussion}

Vulvovaginal candidiasis (VVC) is an infection characterised by vulvovaginal inflammation and the presence of Candida species. VVC is the second most common cause of vaginitis, after bacterial vaginosis, and represents approximately one-third of all vaginitis cases (Workowski and Berman, 2010). The frequency of vaginal 

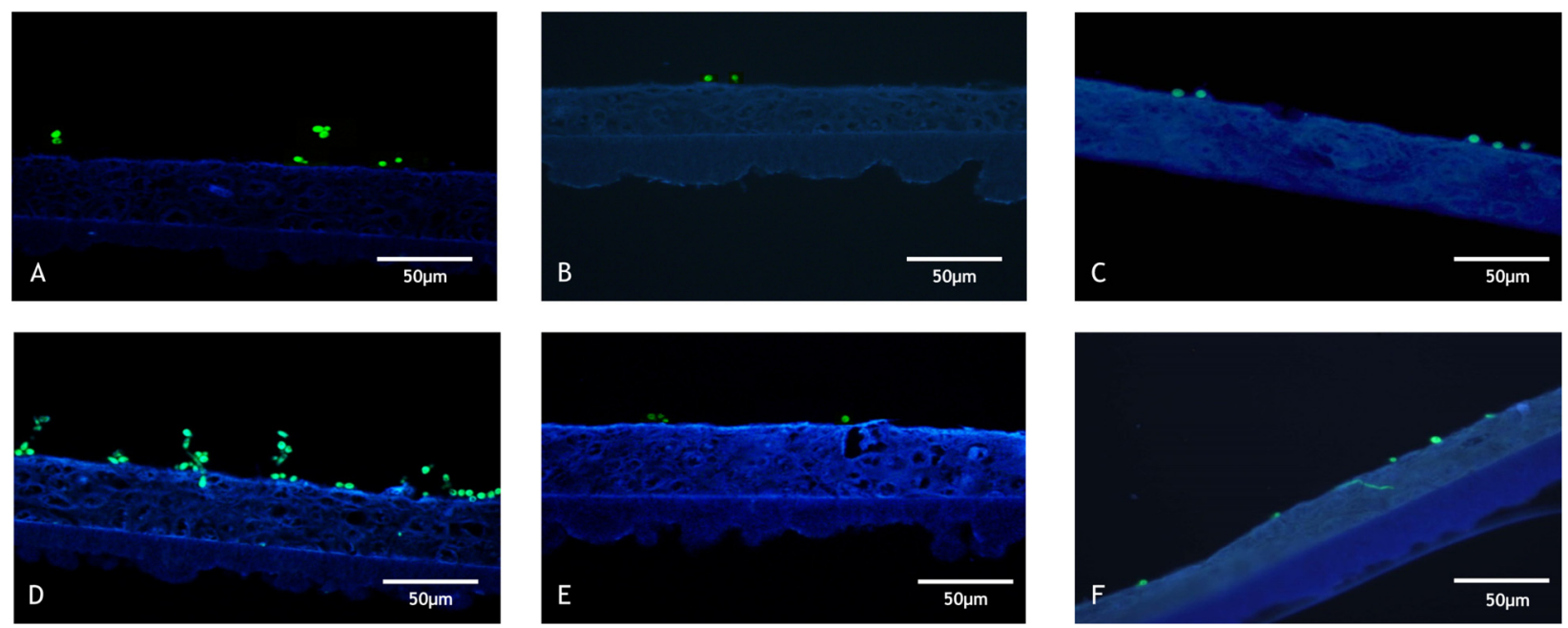

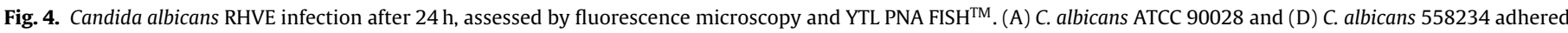

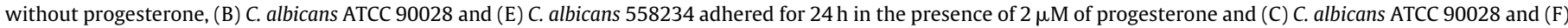
C. albicans 558234 with addition of progesterone after $12 \mathrm{~h}$ of infection.

Table 2

qRT-PCR quantification of $C$. albicans infecting the reconstituted human vaginal epithelium for $24 \mathrm{~h}$ in the presence or absence of $2 \mu \mathrm{M}$ of progesterone.

\begin{tabular}{lll}
\hline $\begin{array}{l}\text { Progesterone } \\
{[2 \mu \mathrm{M}]}\end{array}$ & qRT-PCR ( $\log _{10}$ number of cells $\left./ \mathrm{ml}\right)$ \\
\cline { 2 - 3 } & C. albicans ATCC 90028 & C. albicans 558234 \\
\hline Control & $2.76 \pm 0.11$ & $3.56 \pm 0.13$ \\
Addition at $0 \mathrm{~h}$ & $2.17 \pm 0.15^{* * *}$ & $2.77 \pm 0.21^{* * *}$ \\
Addition at $12 \mathrm{~h}$ & $2.29 \pm 0.17^{* * *}$ & $2.95 \pm 0.12^{* * *}$ \\
\hline
\end{tabular}

*** Statistically different to absence of progesterone $(p<0.001)$.

colonisation by Candida increases with predisposing risk factors such as pregnancy, antibiotic use, immunosuppression, diabetes and HIV infection (De Leon et al., 2002; Sobel et al., 1998).

Progesterone is a C-21 steroid hormone involved in the female menstrual cycle, pregnancy and embryogenesis. Progesterone levels are relatively low during the pre-ovulatory phase of the menstrual cycle, rise after ovulation and are elevated during the luteal phase (Špaček et al., 2007). It has also been shown that Candida has oestrogen and progesterone receptors, that when stimulated, increase fungal proliferation (Reed, 1992). Furthermore, women who take oral contraceptive pills (corresponding to

HWP1

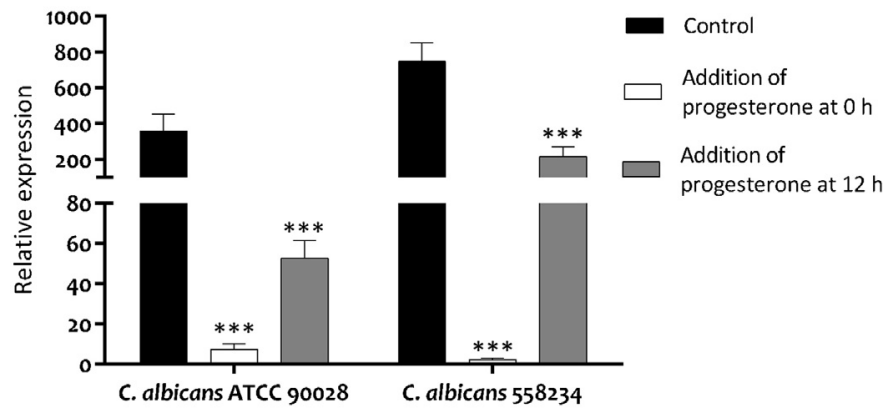

Fig. 5. Relative expression of the hyphal wall protein 1 (HWP1) gene in the absence or presence (added at $0 \mathrm{~h}$ or after $12 \mathrm{~h}$ ) of progesterone during $C$. albicans colonisation of reconstituted human vaginal epithelium. Error bars represent standard deviation. ${ }^{* * *}$ Statistical difference obtained compared to the absence of progesterone $(p<0.001)$. constant high levels of progesterone and oestrogen) have a higher incidence of VVCs (Sobel et al., 1998).

This current study examined the influence of progesterone on $C$. albicans virulence factors, namely biofilm formation and colonisation/invasion of a reconstituted human vaginal epithelium (RHVE).

Initially, experiments were performed to examine the effect of both oestrogen and progesterone on $C$. albicans biofilm formation. However, preliminary studies with oestrogen failed to demonstrate any effects on biofilm formation and therefore the focus was directed towards progesterone.

The effect of progesterone was measured in terms of both number of viable cells and total biomass (Fig. 1), and results were corroborated by SEM (Fig. 2). Oestrogen has previously been shown to be the principle reproductive hormone that supports and sustains experimental vaginal C. albicans infection (Fidel et al., 2000). In contrast, progesterone was found to have no demonstrable effect on vaginal infection or on associated systemic and/or local immune responsiveness. However, in the present study a possible role for progesterone in VVC has been highlighted. It is known that one of the central regulators of biofilm formation is the factor BCR1 (Finkel et al., 2012; Nobile et al., 2006a, 2012). In these current studies expression of $B C R 1$ by $C$. albicans biofilms in the presence of progesterone was significantly reduced (Fig. 3 A). Furthermore, SEM (Fig. 2) revealed a significant decrease in hyphal forms of C. albicans, in the presence of the hormone. In efforts to explain these findings, expression of hyphal wall protein (HWP1) was also measured and again was found to decrease in the presence of progesterone (Fig. 3B). HWP1 is a determinant of $C$. albicans pathogenicity, and involved in biofilm formation (Staab, 1999; Sundstrom et al., 2002). Additional studies have shown that reduced HWP1 gene expression results in thin biofilms and a significant reduction in hyphal mass (Nobile et al., 2006b). Based on the work of this present study, it is possible that progesterone affects $C$. albicans biofilm structure through modulation of the biofilm-associated genes, BCR1 and HWP1.

In order to investigate the influence of progesterone on C. albicans vaginal pathogenicity, a commercially available reconstituted human vaginal epithelium (RHVE, Nice, France) was used. It was evident that both tested $C$. albicans strains could colonise the RHVE (Fig. 4 and Table 2), with limited clusters of cells present within the upper layers of the epithelium and few filamentous forms. However, notably both colonisation and invasion substantially decreased 
in the presence of progesterone, without any apparent alteration of the RHVE (Fig. 4 and Table 2). These results are in accordance with those of Špaček et al. (2007) who showed that progesterone levels in luteal phase of recurrent VVC patients $(6.40 \mathrm{nmol} / \mathrm{L})$ was lower compared with non-infected controls $(34.2 \mathrm{nmol} / \mathrm{L})$.

Down regulation of HWP1 was evident in the presence of progesterone, as verified for biofilms, and was associated with reduced colonisation and invasion. The effect of progesterone on HWP1 expression decreased slightly when added after $12 \mathrm{~h}$ of the infection process. Furthermore, colonisation and invasion of the RHVE by $C$. albicans increased slightly when progesterone was added $12 \mathrm{~h}$ post infection compared to when added at start of RHVE infection. In 1992, Reed had shown that Candida had receptors to progesterone and as these were activated, the degree of pathogenicity increased. The findings of this present study would appear to contradict the findings of Reed (1992), as it would have been expected that a longer exposure to progesterone would have led to increased activation of the receptors leading to enhanced pathogenicity, this was not the case. Furthermore, C. albicans 558234 expressed higher levels of HWP1 (Fig. 5) when progesterone was added $12 \mathrm{~h}$ post infection, compared to those infections with progesterone presence for $24 \mathrm{~h}$. These findings were supported by hyphal detection using fluorescence microscopy (Fig. 4 F).

In summary, progesterone was able to modulate $C$. albicans biofilm formation (cell viability, total biomass and structure), as well as the colonisation and invasion of RHVE. These effects may relate to the down regulation of the biofilm-related genes BCR1 and HWP1 by progesterone. Additionally, HWP1 gene expression by $C$. albicans infecting RHVE suggests an important role of progesterone in hyphal development. If these effects can be extrapolated to the in vivo situation then relative progesterone levels may play important roles in the progression of $C$. albicans vaginal infection.

The authors declare no conflicts of interest.

\section{Acknowledgements}

We would like to thank Mrs Lucília Goreti Pinto for processing and sectioning tissue samples. This work was supported by the research grant SFRH/BD/72742/2010 and projects PTDC/EBBEBI/120495/2010 and PEst-OE/EQB/LA0023/2013 from "Fundação para a Ciência e Tecnologia" (FCT), Portugal. The authors also thank the Project "BioHealth-Biotechnology and Bioengineering approaches to improve health quality", Ref. NORTE-07-0124FEDER-000027, co-funded by the Programa Operacional Regional do Norte (ON.2-O Novo Norte), QREN, FEDER.

\section{References}

Altschul, S.F., Madden, T.L., Schäffer, A.A., Zhang, J., Zhang, Z., Miller, W., Lipman, D.J., 1997. Gapped BLAST and PSI-BLAST: A new generation of protein database search programs. Nucleic Acids Res. 25, 3389-3402.

Calderone, R., Gow, N., 2002. Host recognition by Candida species. In: Calderone, R (Ed.), Candida and Candidiasis. , pp. 67-86, Washington, DC.

Douglas, L.J., 2003. Candida biofilms and their role in infection. Trends Microbiol. 11, 30-36.

Eggimann, P., Garbino, J., Pittet, D., 2003. Epidemiology of Candida species infections in critically ill non-immunosuppressed patients. Lancet Infect. Dis. 3, $685-702$.

Fanning, S., Xu, W., Solis, N., Woolford, C.A., Filler, S.G., Mitchell, A.P., 2012. Divergent targets of Candida albicans biofilm regulator BCR1 in vitro and in vivo. Eukaryot. Cell 11, 896-904.
Fidel Jr., P., Cutright, J., Steele, C., 2000. Effects of reproductive hormones on experimental vaginal candidiasis. Infect. Immun. 68, 651-657.

Finkel, J.S., Xu, W., Huang, D., Hill, E.M., Desai, J.V., Woolford, C.A., Nett, J.E., Taff, H., Norice, C.T., Andes, D.R., et al., 2012. Portrait of Candida albicans adherence regulators. PLoS Pathog. 8, e1002525.

Foxman, B., Muraglia, R., Dietz, J.-P., Sobel, J.D., Wagner, J., 2013. Prevalence of recurrent vulvovaginal candidiasis in 5 European countries and the United States: results from an internet panel survey. J. Low. Genit. Tract Dis. 17, 340-345.

Kalo, A., Segal, E., 1988. Interaction of Candida albicans with genital mucosa: Effect of sex hormones on adherence of yeasts in vitro. Can. J. Microbiol. 34, 224-228.

De Leon, E.M., Jacober, S.J., Sobel, J.D., Foxman, B., 2002. Prevalence and risk factors for vaginal Candida colonization in women with type 1 and type 2 diabetes. BMC Infect. Dis. 2, 1.

Livak, K.J., Schmittgen, T.D., 2001. Analysis of relative gene expression data using real-time quantitative PCR and the 2(-Delta Delta C(T)) method. Methods 2540 , $2-8$.

Miller, L., Patton, D.L., Meier, A., Thwin, S.S., Hooton, T.M., Eschenbach, D.A., 2000 Depomedroxyprogesterone-induced hypoestrogenism and changes in vaginal flora and epithelium. Obstet. Gynecol. 96, 431-439.

Nobile, C.J., Andes, D.R., Nett, J.E., Smith, F.J., Yue, F., Phan, Q.-T., Edwards, J.E., Filler S.G., Mitchell, A.P., 2006a. Critical role of BCR1-dependent adhesins in C. albicans biofilm formation in vitro and in vivo. PLoS Pathog. 2, e63.

Nobile, C.J., Nett, J.E., Andes, D.R., Mitchell, A.P., 2006b. Function of Candida albicans adhesin HWP1 in biofilm formation. Eukaryot. Cell, 1604-1610.

Nobile, C.J., Fox, E.P., Nett, J.E., Sorrells, T.R., Mitrovich, Q.M., Hernday, A.D., Tuch, B.B., Andes, D.R., Johnson, A.D., 2012. A recently evolved transcriptional network controls biofilm development in Candida albicans. Cell 148, 126-138.

Nohmi, T., Abe, S., Dobashi, K., Tansho, S., Yamaguchi, H., 1995. Suppression of anti-Candida activity of murine neutrophils by progesterone in vitro: A possible mechanism in pregnant women's vulnerability to vaginal candidiasis. Microbiol. Immunol. 39, 405-409.

Ramage, G., Saville, S.P., Thomas, D.P., López-Ribot, J.L., 2005. Candida biofilms: An update. Eukaryot. Cell 4, 633-638.

Ramage, G., Rajendran, R., Sherry, L., Williams, C., 2012. Fungal biofilm resistance. Int. J. Microbiol. 2012, 528521

Reed, B., 1992. Risk factors for Candida vulvovaginitis. Obs. Gynecol. Surv. 47, $551-560$.

Sardi, J.C.O., Scorzoni, L., Bernardi, T., Fusco-Almeida, A.M., Mendes Giannini, M.J.S., 2013. Candida species: Current epidemiology, pathogenicity, biofilm formation, natural antifungal products and new therapeutic options. J. Med. Microbiol. 62, $10-24$.

Silva, S., Henriques, M., Martins, A., Oliveira, R., Williams, D., Azeredo, J., 2009 Biofilms of non-Candida albicans Candida species: Quantification, structure and matrix composition. Med. Mycol. 47, 681-689.

Skrzypek, M.S., Arnaud, M.B., Costanzo, M.C., Inglis, D.O., Shah, P., Binkley, G., Miyasato, S.R., Sherlock, G., 2010. New tools at the Candida genome database: Biochemical pathways and full-text literature search. Nucleic Acids Res. 38, D428-D432.

Sobel, J.D., 1992. Pathogenesis and treatment of recurrent vulvovaginal candidiasis. Clin. Infect. Dis. 14, S148-S153.

Sobel, J.D., Faro, S., Force, R.W., Foxman, B., Ledger, W.J., Nyirjesy, P.R., Reed, B.D., Summers, P.R., 1998. Vulvovaginal candidiasis: Epidemiologic, diagnostic and therapeutic considerations. Am. J. Obstet. Gynecol. 178, 203-211.

Špaček, J., Buchta, V.,Jílek, P., Förstl, M., 2007. Clinical aspects and luteal phase assessment in patients with recurrent vulvovaginal candidiasis. Eur. J. Obstet. Gynecol. Reprod. Biol. 131, 198-202.

Spinillo, A., Capuzzo, E., Acciano, S., De Santolo, A., Zara, F., 1999. Effect of antibiotic use on the prevalence of symptomatic vulvovaginal candidiasis. Am. J. Obstet. Gynecol. 180, 14-17.

Staab, J.F., 1999. Adhesive and mammalian transglutaminase substrate properties of Candida albicans HWP1. Science (80) 283, 1535-1538.

Sundstrom, P., Balish, E., Allen, C.M., 2002. Essential role of the Candida albicans transglutaminase substrate, hyphal wall protein 1, in lethal oroesophageal candidiasis in immunodeficient mice. J. Infect. Dis. 185, 521-530.

Taguti Irie, M.M., Lopes Consolaro, M.E., Aparecida Guedes, T., Donatti, L., Valéria Patussi, E., Estivalet Svidzinski, T.I., 2006. A simplified technique for evaluating the adherence of yeasts to human vaginal epithelial cells. J. Clin. Lab. Anal. 20, 195-203.

Trick, W.E., Fridkin, S.K., Edwards, J.R., Hajjeh, R.A., Gaynes, R.P., 2002. Secular trend of hospital-acquired candidemia among intensive care unit patients in the United States during 1989-1999. Clin. Infect. Dis. 35, 627-630.

Williams, D.W., Wilson, M.J., Lewis, M.A., Potts, A.J., 1995. Identification of Candida species by PCR and restriction fragment length polymorphism analysis of intergenic spacer regions of ribosomal DNA. J. Clin. Microbiol. 33, 2476-2479.

Workowski, K., Berman, S., 2010. Sexually transmitted diseases treatment guidelines, 2010. MMWR Recomm. Rep. 17, 1-110. 